\title{
The effect of knowledge management on competitive advantage and business performance: A study of silver craft SMEs
}

\author{
Putu Yudy Wijaya, Ni Nyoman Reni Suasih
}

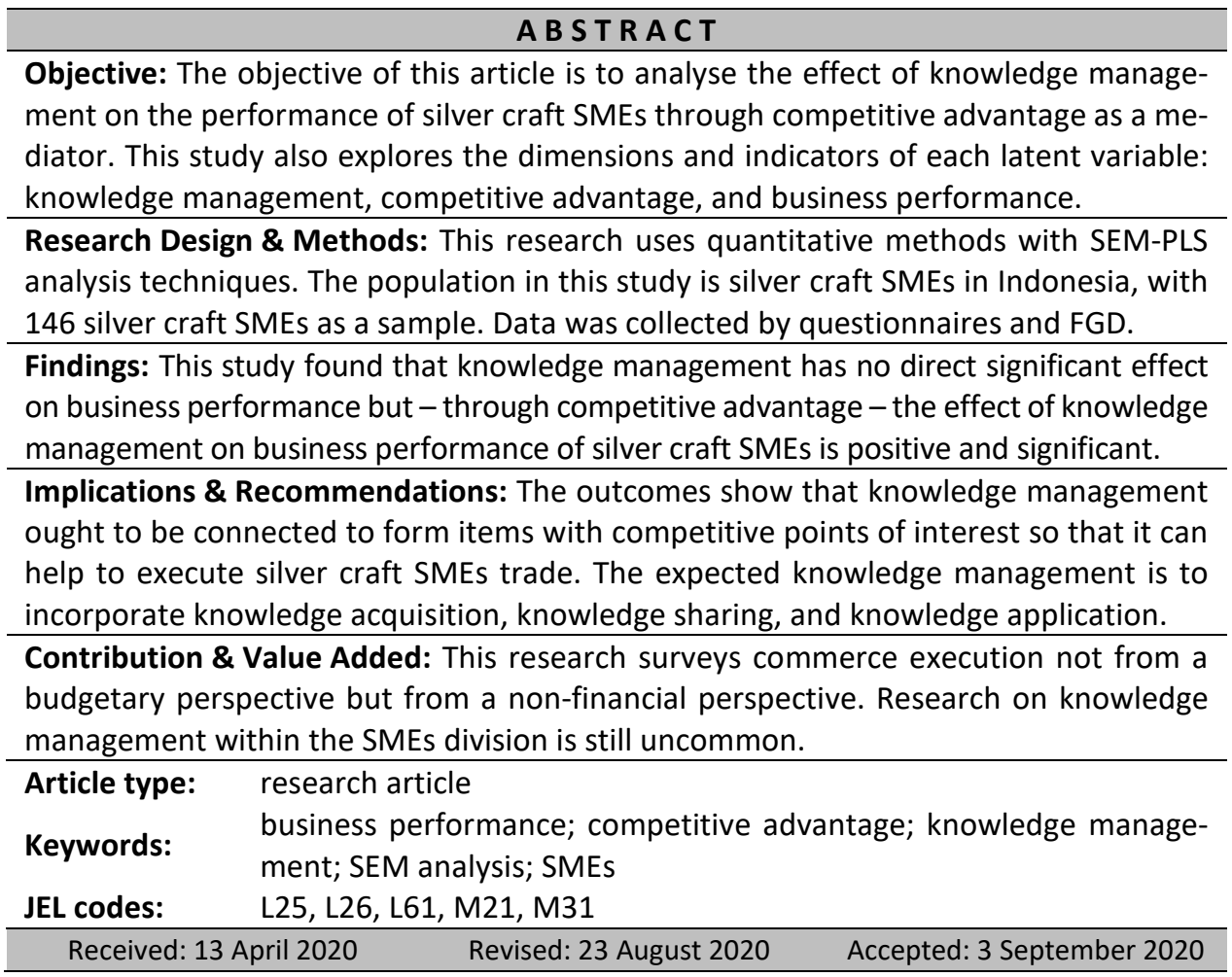

\section{Suggested citation:}

Wijaya, P.Y., \& Suasih, N.N.R. (2020). The Effect of Knowledge Management on Competitive Advantage and Business Performance: A Study of Silver Craft SMEs. Entrepreneurial Business and Economics Review, 8(4), 105-121. https://doi.org/10.15678/EBER.2020.080406 


\section{INTRODUCTION}

Small and medium enterprises (SMEs) play an imperative part in supporting a country's financial development, both in developed and developing countries: New Zealand, India, Sri Lanka, China, Malaysia, Indonesia (Apak \& Atay, 2014; Darroch, 2005; Ha, Lo, \& Wang, 2016; Huang \& Li, 2009; Kumarawadu, 2009; Kuncoro \& Suriani, 2018; Meutia \& Ismail, 2013; Budhi, Lestari, Suasih, \& Wijaya, 2020). SMEs have the advantage of being able to absorb large numbers of workers while using relatively large local resources, as a chain for distributing development results and supporting various types of industrial sectors (Tan, Mavondo, \& Worthington, 2016). Barriers to the development of SMEs in Indonesia can be grouped into two obstacles, namely external and internal. External barriers include (1) limited access to business financing caused by the high cost of funds and guarantees, (2) high infrastructure costs due to high logistics costs stemming from the poor quality of roads, ports, airports, funding, and legal issues, and (3) inefficient bureaucratic services caused by high levels of corruption and the ratio of civil servants compared to high population. Internal barriers include (1) institutional and human resources, (2) marketing and technology, and (3) intellectual capital (Budhi, Lestari, Suasih, \& Wijaya, 2020).

Indonesia is a country with many SMEs which number 64,194 million units of SMEs (Ministry of Cooperation and SMEs of the Republic of Indonesia, 2018). SMEs in creative industries - including crafts - are growing rapidly. Indonesian silver jewellery products are already recognised in the international market putting the country as the world's seventh largest exporter of silver jewellery with a market share of some $5.17 \%$. Most of Indonesian silver jewellery products are exported to Asian and European markets (Directorate General of National Export Development, 2016). The most well-known silver crafting centre in Indonesia is located in Celuk Village, Sukawati District, Gianyar Regency, Bali Province (Directorate General of National Export Development, 2012).

As one of the world tourist destinations Bali can support the existence of SME's crafts. Jewellery craft SME's is one of the five main commodities exported by Bali Province. Most adornments in Bali Province comes from the silver industry. The head of Industry and Trade Office of Bali Province said that the value of Bali silver exports in 2012-2018 experienced a downward trend. The results of initial observations reveal that one of the obstacles is the lack of skills among employees, but also low competitiveness.

As one of the imperative resources of a company organisation, knowledge must be successfully recognised, captured, stored, shared, and connected in the most productive way to attain economical competitive advantage (Kaveh, Bamipur, Far, \& Far, 2015; Sarkindaji, 2014). SMEs appear to depend more on the advancement of their inner abilities to bolster advancement (Wijaya, Rahyuda, Yasa, \& Sukaatmadja, 2019). Knowledge is seen as the most vital competitive asset. Given the significance of knowledge, business visionaries are motivated to create capacities in overseeing information so that they become more competitive and imaginative (Ha, Lo, \& Wang, 2016). Knowledge management is an integrative systematic process used to clearly coordinate organisational activities, identify cognitive needs, transfer, store, share, and apply knowledge related to culture and business strategy (Alrubaiee, Hanandeh, \& Ali, 2015; Byukusenge, Munene, \& Orobia, 2016). Human resources or knowledge management is a source that can create sustainable competitive advantages (Kamya, Ntayi, \& Ahiauzu, 2010; Kaveh Bamipur, Far, \& Far, 2015). Experience, intelligence, 
and knowledge are intangible factors associated with this source (Madan \& Khanka, 2011). Intangible assets in the form of knowledge management owned by business actors are their unique advantages because it is difficult to imitate other business actors. Effective knowledge management enables SMEs to improve their business behaviour.

Knowledge acquisition and sharing impacts competitive advantage. Concern for knowledge plays an important role in increasing competitiveness (Kamya, Ntayi, \& Ahiauzu, 2010). Utilising company resource-based expertise and dynamic perspectives are absolutely necessary to create competitiveness (Adams \& Lamont, 2003).

A few scholarly investigations state that knowledge management is considered a key figure in business performance since it relates to diverse assets so that it can offer assistance to decision-makers in numerous ways (Alrubaiee, Hanandeh, \& Ali, 2015; Carneiro, 2000; Goel \& Rich, 1997; Keen, 1991). Knowledge management directly and significantly impacts the performance of both financial and non-financial businesses (Al-Sa'di, Abdallah, \& Dahiyat, 2017; Migdadi, Zaid, Yousif, Almestarihi, \& Al-Hyari, 2017; Oztekin, Delen, Zaim, Turkyilmaz, \& Zaim, 2015; Sarkindaji, Bin Hashim, \& Abdullateef, 2014). Knowledge is always needed in business as information to understand the condition of customers, suppliers, employees, competitors, and the entrepreneurial environment in order to achieve competitiveness (Byukusenge, Munene, \& Orobia, 2016).

Today, the business faces intense competition among businesspeople and risks easily losing customers. This is because businesspeople do not understand and respond to rapidly changing market trends. The role of knowledge is needed to move to knowledge management practices ( $\mathrm{Ha}$, Lo, \& Wang, 2016).

Valmohammadi and Ahmadi (2015) found that knowledge management practices did not affect the organisation's business performance, especially seen from the perspective of customers and internal business. Tanriverdi (2005) discovered a frail relationship between a company's monetary execution and its capacity to form, share, coordinate, and utilise knowledge. Byukusenge, Munene, and Orobia (2016) found that knowledge management had a non-significant effect on business performance in business. Knowledge gained from short courses, conferences, exhibitions, qualified staff, and sharing among employees cannot be used directly to generate profits, sales growth, and market share.

The current article places knowledge management as the only exogenous variable, so that its effectiveness on business performance can be known, especially in the creative industries. Creative industries have different characteristics from other industries, in which the former employ creativity that comes from knowledge as the main factor in creating products. Therefore, research on knowledge management is necessary and original.

Research on knowledge management is not very common, but it has recently begun to gain popularity. When compared with previous research, this study tries to map the effects of knowledge management in the creative industry (silver crafts) on competitive advantage and performance. The current study uses financial and non-financial aspects to measure business performance. Abu-Jarad, Yusof, and Nikbin (2010) foreground that an organisation's commerce execution is its capacity to realise its objectives and goals by utilising financial, productive, and viable assets.

The current study aims to explore the factors that influence knowledge management to create competitive advantage and corporate performance in silver industry SMEs in Gianyar Regency, Bali. This study emphasises that the competency development of employers is 
good from internal factors, namely knowledge management in enhancing competitive advantage and business performance. By receiving a resource-based view (RBV) as an established hypothesis upheld by Porter Theory (competitive advantage), we propose a system by highlighting key variables that can drive the performance of SMEs. Competitive advantage is the advantage over a competitor by gaining more esteem among customers either at a lower cost or by offering items that give much better benefits.

This research uses quantitative methods with SEM-PLS analysis techniques. The population in this study is silver craft SMEs in Indonesia. We collected data through questionnaire instruments that were tested for validity and reliability through Focus Group Discussion (FGD).

The introduction presented the foundation and targets of our article. The literature review section scrutinises past ideas about the topic of the article. The research method section presents investigation's plan, populace, and tests, but also information collection and methods of analysis. The results and discussion section deliberates the study results, while the conclusion section considers the study limitations and recommendations for future research.

\section{LITERATURE REVIEW}

Based on empirical evidence, knowledge management has a positive and significant effect on competitive advantage (Adams \& Lamont, 2003; Kamya, Ntayi, \& Ahiauzu, 2010; Kaveh, Bamipur, Far, \& Far, 2015), while the influence of competitive advantage on business performance is positively and significantly based on research results done by Meutia and Ismail (2013), Mzoughi, Bahri, and Ghachem (2008), and Rahman and Ramli (2014). These empirical results allow us to assume the following research hypotheses:

H1: Knowledge management positively and significantly affects competitive advantage.

Business always needs knowledge as information to understand the condition of customers, suppliers, employees, competitors, and the entrepreneurial environment so that business can remain competitive (Byukusenge, Munene, \& Orobia, 2016). Several studies have been conducted on the role of knowledge management on business performance, including those carried out by Al-Sa'di, Abdallah, and Dahiyat (2017), Alrubaiee, Hanandeh, and Ali (2015), and Migdadi, Zaid, Yousif, Almestarihi, and Al-Hyari (2017), who found that knowledge management processes have a positive and significant influence on organisational performance. Previous studies are supported by the discoveries of Sarkindaji, Bin Hashim, and Abdullateef (2014) who clarify that organisations interested in maintaining competitive advantage must create and combine great knowledge management procedures.

These empirical results allow us to assume the following research hypothesis:

H2: Knowledge management positively and significantly affects business performance.

Achieving the position of competitive advantage and improving a company's performance against competitors are the two main objectives of business organisation that the company must try to achieve. Companies that have an advantage in terms of products, price, and quality will certainly be competitive so that their products will be bought by customers. This can increase sales and advertisement, progressing the company's business performance. This condition is supported by several results found by Meutia and Ismail 
(2013), Mzoughi, Bahri, and Ghachem (2008), and Rahman and Ramli (2014), who state that competitive advantage can significantly improve business performance.

These empirical results allow us to assume the following research hypothesis:

H3: Competitive advantage positively and significantly affects business performance.

Competitive advantage can explain the mediating relationship of quality on organisational performance (Lakhal, 2009). The use of a quality approach can give organisational competitive advantage in terms of unwavering quality, development, and time-to-market measurements. The higher level of competitive advantage compared to competitors will certainly increase organisational performance. Similar results were stated by Kamboj and Rahman (2017) who explain that competitive advantage can partly mediate between the influence of marketing capabilities on company performance.

These empirical results allow us to assume the following research hypothesis:

H4: Competitive advantage significantly mediates the effect of knowledge management on business performance.

\section{RESEARCH METHODOLOGY}

This study uses explanatory research design with a quantitative approach. According to Rahyuda (2016), explanatory research is done by explaining the symptoms caused by the object of research. The research variables studied are quantitative, meaning the types of data are based on quantitative data (Rahyuda, 2016).

This research stage includes the following phases: (1) describing the research gap; (2) setting goals; (3) developing a conceptual framework and hypothesis; (4) determining the research method; (5) arranging and testing the instrument; (6) collecting data; (7) analysing data; (8) interpreting results and test hypotheses; (9) assembling conclusions and recommendations. The process of collecting data uses a perceptual approach to facilitate measurement. In the early stages of the study, we conducted a preliminary study later followed by the distribution of questionnaires based on the literature review. The results of the research were then analysed to test the research hypotheses using quantitative analysis.

\section{Population, Sample, and Data Collection}

Gianyar Regency is the centre of silver industry in Bali Province, so this research was conducted on silver craft SMEs in Gianyar Regency. The research subjects were entrepreneurs in small and medium-sized enterprises (SMEs), especially silver handicraftsmen who are currently the leading exporters in Gianyar Regency.

Based on data from the Industry Office of Gianyar Regency, in 2017, there were 235 business units of silver craft SMEs in Indonesia, mostly based in Gianyar Regency. The determination of the number of samples in this study - using the formula of Issac and Michael (the level of significance is 0.05 ) - allowed us to obtain a total sample of 146 business units of silver craft SMEs in Gianyar Regency. Next, the simple random sampling technique was used, wherein the sample was taken randomly.

\section{Measures}

The construction of latent variable constructs of knowledge management, competitive advantage, and business performance is often debated by many researchers. To create a 
variable construct, we must study various concepts from previous research and adapt them to the conditions of the research object. This construction is used as the basis for the preparation of a questionnaire which will be the research instrument. Our research instrument has met the validity test criteria with product moment correlation (Pearson corelation) and reliability test with Cronbach's alpha. All of the measures are based on five-point Likert scales. Knowledge management variables are exogenous, while business performance variables are endogenous and competitive advantage variables are mediator variables. In detail, the dimensions and indicators of each variable are presented in Table 1.

Table 1. Operational Definition of Variables

\begin{tabular}{|c|c|c|}
\hline Variable & Dimension & Indicator \\
\hline \multirow[t]{3}{*}{$\begin{array}{l}\text { Knowledge man- } \\
\text { agement }(X)\end{array}$} & Knowledge acquisition (X1) & $\begin{array}{l}-\quad \text { Knowledge from employees (X11) } \\
-\quad \text { Training for employees (X12) }\end{array}$ \\
\hline & Knowledge sharing (X2) & $\begin{array}{l}- \text { Information sharing (X21) } \\
-\quad \text { Developing of new ideas (X22) }\end{array}$ \\
\hline & $\begin{array}{l}\text { Knowledge application } \\
\text { (X3) }\end{array}$ & $\begin{array}{l}-\quad \text { Knowledge practical (X31) } \\
-\quad \text { Management of knowledge and resources (X32) }\end{array}$ \\
\hline
\end{tabular}

(References: Al-Sa'di, Abdallah, \& Dahiyat, 2017; Alrubaiee, L, Hanandeh \& Ali, 2015; Byukusenge, Munene, \& Orobia, 2016; Darroch \& Mcnaughton, 2002; Huang \& Li, 2009; Kamya, Ntayi, \& Ahiauzu, 2010; Kumarawadu, 2008; Migdadi, Zaid, Yousif, Almestarihi, \& Al-Hyari, 2017; Obeidat, Al-Suradi, Masa'deh, \& Tarhini, 2016; Oztekin, Delen, Zaim, \& Turkyilmaz, 2015; Sarkindaji, Bin Hashim, \& Abdullateef, 2014; C. L. Wang, Hult, Ketchen, \& Ahmed, 2009)

\begin{tabular}{|l|l|l|}
\hline $\begin{array}{l}\text { Competitive ad- } \\
\text { vantage }(\mathrm{Y})\end{array}$ & Efficiency $(\mathrm{Y} 1)$ & - Cost efficiency $(\mathrm{Y} 11)$ \\
\cline { 2 - 3 } & Product uniqueness (Y2) & - Productivity $(\mathrm{Y} 12)$ \\
& & - Product shape $(\mathrm{Y} 21)$ \\
\cline { 2 - 3 } & Quality (Y3) & - Product quality $(\mathrm{Y} 31)$ \\
& - Product display (Y32) \\
\cline { 2 - 3 } & Competitive price (Y4) & - Product price (Y41) \\
& - Price comparison (Y42) \\
\cline { 2 - 3 } & Flexibility (Y5) & - Product variants (Y51) \\
& - Product adaptation (Y52) \\
\hline
\end{tabular}

(References: Apak \& Atay, 2014; Aziz \& Samad, 2016; Chiou, Chan, Lettice, \& Chung, 2011; Diab, 2013; Ismail, Rose, Abdullah, Uli, 2010; Kumarawadu, 2009; Kuncoro \& Suriani, 2018; Rahman \& Ramli, 2014; Sachitra, 2016; Ward, McCreery, Ritzman, \& Sharma, 1998; Wijaya, Rahyuda, Yasa, \& Sukaatmadja, 2019) \begin{tabular}{|l|l|l|}
\hline Business perfor- & Financial (Z1) & - Liquidity (Z11)
\end{tabular} mance (Z)

\begin{tabular}{|l|l|}
\hline Financial (Z1) & - Liquidity (Z11) \\
& - Rentability (Z12) \\
\hline Customer (Z2) & - Number of customers (Z21) \\
& - Customer satisfaction (Z22) \\
\hline Operational (Z3) & - Product operations (Z31) \\
& - Operational management (Z32) \\
\hline Learning and growth (Z4) & - Learning for employees (Z41) \\
& - Employees satisfaction (Z42) \\
\hline
\end{tabular}

(References: Al-Sa'di, Abdallah, \& Dahiyat, 2017; Alrubaiee, Hanandeh, \& Ali, 2015; Byukusenge, Munene, \& Orobia, 2016; Ha, Lo, \& Wang, 2016; Kamboj \& Rahman, 2017; Kipesha, 2013; Kuhl, Cunha, Macaneiro, \& Cunha, 2016; Migdadi, Zaid, Yousif, Almestarihi, \& Al-Hyari, 2017; Oztekin, Delen, Zaim, Turkyilmaz, \& Zaim, 2015; Sarkindaji, Bin Hashim, \& Abdullateef, 2014; Tseng \& Lee, 2014; Valmohammadi \& Ahmadi, 2015; Wang \& Wang, 2012; Yousif Al-Hakim \& Hassan, 2013; Yusof \& Bakar, 2012; Wijaya, Rahyuda, Yasa, Sukaatmadja, 2019)

Source: own study. 


\section{Statistical Methods}

Factual investigation in this study comprised of expressive and inferential examination. Graphic investigation was utilised to analyse information by describing collected information (Sugiyono, 2013). Inferential factual examination methods with the examination approach were utilised to test the research hypotheses. Handling information that utilises the way investigation approach with SEM-PLS (Auxiliary Condition Modelling-Partial Slightest Square) arrange corroborative calculate examination (Ghozali, 2012). Agreeing to (Latan \& Ghozali, 2012), the assessment of models in PLS was done by evaluating the effects of the estimation, specifically through corroborative calculation of the examination by testing the legitimacy and unwavering quality of idle builds. At that point, we assessed the basic models and tested for centrality to test the impact between builds or factors.

\section{RESULTS AND DISCUSSION}

\section{Results of Outer and Inner Model Testing}

A demonstration built on a coherent hypothetical premise was created to test the hypotheses. SmartPLS 3.2.8 was utilised for the investigation. The primary step was to survey the unwavering quality and legitimacy of the estimation. Next, a basic demonstration was utilised to test the speculations.

The SEM-PLS investigation procedure was conducted in two stages of investigation, specifically by testing the external demonstration and then by testing the internal demonstration. External testing points to the legitimacy and reliability of pointers in building measurements, but also to measurements in building each variable. Testing the inward demonstrate was to decide the relationship among factors.

\section{Outer model testing}

The results of the outer model analysis - as presented in Figure 1 - showed that there are three indicators that were invalid because they had an outer loading smaller than 0.6.

Indicators that did not meet the testing criteria for the outer model were indicators of knowledge and resource management (X32) in the knowledge management variable $(X)$, but also indicators (Z32) and (Z41) in the business performance (Z) variable. Thus, the three indicators were eliminated from the model and the outer model is tested again.

The output of the second phase of the outer model test is shown in Figure 2. Based on the output in Figure 2, we know that all indicators met the validity criteria for the outer model.

\section{Inner Model Testing}

The following step is to test the internal demonstration by considering the R-square esteem $\left(R^{2}\right)$ on endogenous factors (trade execution). The effects of information investigation revealed that the $R$-square esteem was 0.220 , which suggests that $22.0 \%$ of the variety within the commerce execution of silver craftsmanship SMEs in Gianyar Rule can effect from information administration and competitive advantage. The remaining $78 \%$ is clarified by other variables, external to the research model.

Another internal step was to assess the coefficient, as displayed in Figure 3. 


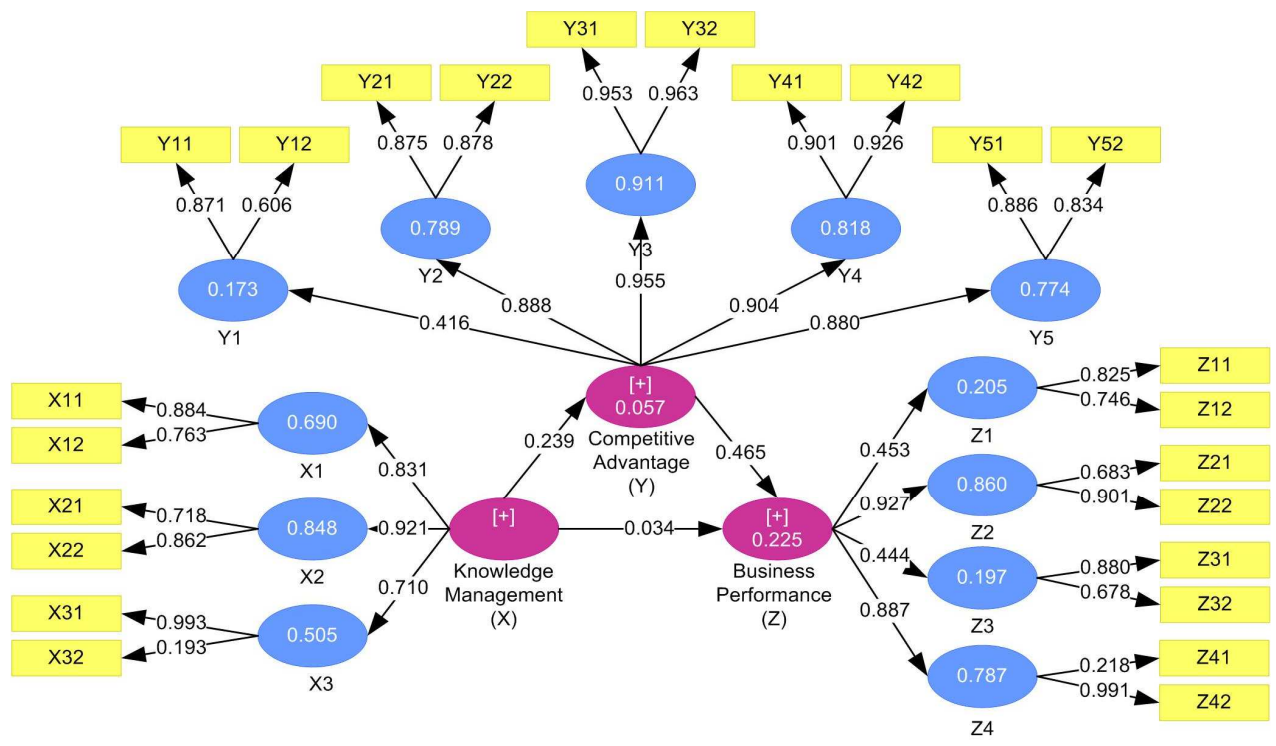

Figure 1. Outer model before elimination the invalid indicators

Source: own elaboration with SmartPLS (2019).

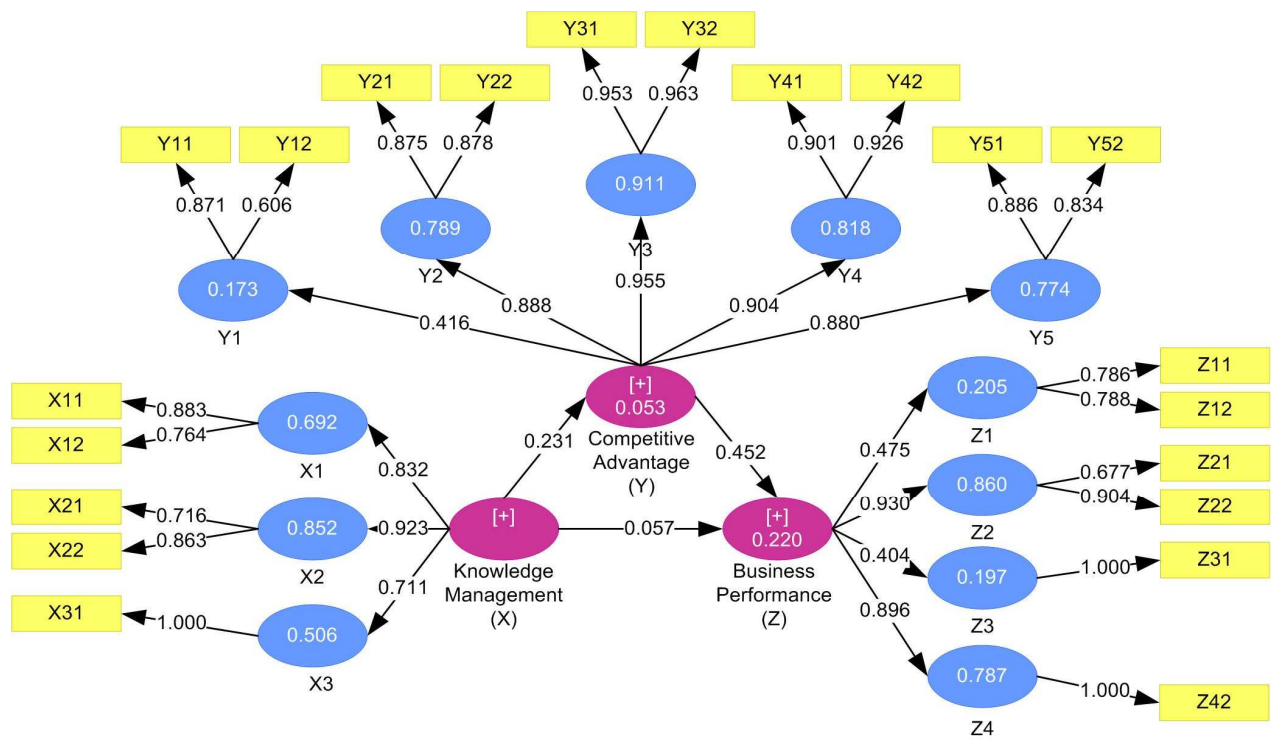

Figure 2. Outer model (after elimination the invalid indicators)

Source: own elaboration with SmartPLS (2019). 


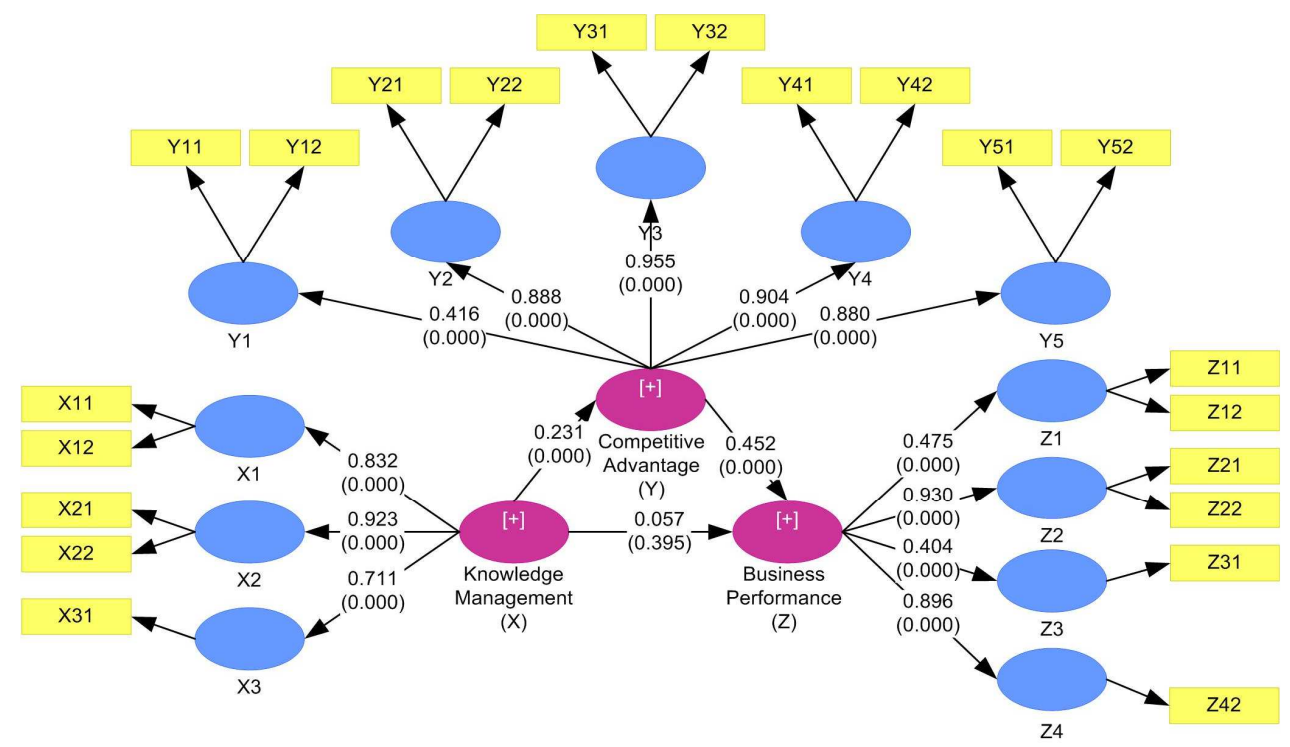

Figure 3. Inner model

Source: own elaboration with SmartPLS (2019).

Table 2. Path coefficient (direct and indirect Effect) and hypotheses results

\begin{tabular}{|l|c|c|c|c|}
\hline \multicolumn{1}{|c|}{ Path, Direct effects } & Path Coefficient & T Statitics & P Values & Hypotheses Result \\
\hline $\begin{array}{l}\text { Knowledge management } \rightarrow \\
\text { competitive advantage }\end{array}$ & 0.231 & 3.610 & 0.000 & H1 supported \\
\hline $\begin{array}{l}\text { Knowledge management } \rightarrow \\
\text { business performance }\end{array}$ & 0.057 & 0.852 & 0.395 & H2 not supported \\
\hline $\begin{array}{l}\text { Competitive advantage } \rightarrow \\
\text { business performance }\end{array}$ & 0.452 & 5.216 & 0.000 & H3 supported \\
\hline \begin{tabular}{l} 
Indirect effects: \\
\hline $\begin{array}{l}\text { Knowledge management } \rightarrow \\
\text { competitive advantage } \rightarrow \\
\text { business performance }\end{array}$
\end{tabular} & 0.104 & 0.206 & 0.014 & H4 supported \\
\hline R2 & $22.0 \%$ & & & \\
\hline
\end{tabular}

Source: own elaboration with SmartPLS (2018).

Figure 3 and Table 2 show the results of data analysis that knowledge management has a directly positive and significant effect on competitive advantage ( $p$-value 0.000 $<0.05$ ), while knowledge management turns out to have no direct significant effect on business performance ( $p$-value $0.395>0.05$ ). Competitive advantage has a directly positive and significant effect on business performance ( $p$-value $0.000<0.05)$. Likewise, the influence of knowledge management indirectly affects business performance positively and significantly through competitive advantage ( $p$-value $0.014<0.05$ ). Given that the direct effect of knowledge management on business performance is not significant, the indirect effect of knowledge management on business performance through competitive advantage is full mediation. 


\section{DISCUSSION}

In an effort to improve competitiveness, knowledge acquisition is conducted by silver craft SMEs through hiring new employees, along with attending training and seminars as sources of new knowledge. Most silver handicrafts do not rely on a single group of employees to complete product orders from customers. They generally employ several groups of artisans/employees to work on product orders. This aims to minimise production costs and reduce the cost of material inventory, so that companies become efficient. Silver craft SMEs encourage employees/artisans to take part in workshops, seminars, and short courses, such as expert 3D design with computer software. This approach has proven to produce unique products, both in terms of form and design, so that they have competitiveness in the market.

Sharing knowledge and information between business operators in silver handicrafts and partners often happens when receiving product orders. One form of knowledge and information sharing activity is through discussion about the types and variety of silver handicraft products that are in accordance with market tastes. The lack of access to information from business operators in silver handicrafts - compared to their customers - requires them to do knowledge sharing more often. The aim is for business operators in silver craft SMEs to quickly adapt to market tastes.

Knowledge management produces ideas. Based on the results of interviews with several silver craft SMEs, their ideas or knowledge were unable to directly improve business performance. The idea must be able to be realised in the form of quality products and accepted by the market. Some silver craft SMEs rarely do knowledge sharing because they fear that the knowledge they have become known or understood by others, so that the expertise to produce products is copied by others.

The results of this study support previous studies by Carneiro (2000), Kamya, Ntayi, and Ahiauzu (2010), and Kaveh, Bamipur, Far, and Far (2015). Knowledge management must be able to combine advancement endeavours, IT overhauls, and knowledge advancement so as to attain a set of capabilities to make strides in competitiveness. Knowledge management has been considered a key figure in organisational execution, since it is related with distinctive assets that can offer assistance to producers in numerous ways (Carneiro, 2000).

The ability of silver craftsmen (SMEs manager/owner) to produce competitive products (in terms of efficiency, quality, uniqueness, price, and flexibility product) will provide customer satisfaction, increase sales value and market share, also make products competitive in the market.

The results of this study contradict previous studies which have consistently supported significant and positive influence of knowledge management on SMEs business performance. The research results from Alrubaiee, Hanandeh, and Ali (2015), Al-Sa'di, Abdallah, and Dahiyat (2017), and Migdadi, Zaid, Yousif, Almestarihi, and Al-Hyari (2017) found that companies with more knowledge management show higher performance.

The results of this research agree with the investigations of Tanriverdi (2005) and Byukusenge, Munene, and Orobia (2016). Tanriverdi (2005) found an inconsequential relationship between the capacity to form, share, coordinate, and utilise knowledge in a company's commerce. Byukusenge, Munene, and Orobia (2016) argues that knowledge received through brief courses, classes, presentations, or qualified staff is shared with all 
employees. Such knowledge cannot straightforwardly cause a noteworthy change in benefits, development, and advertisement of SMEs. The critical relationship between knowledge management and business performance caused by the SMEs managers who anticipate the surge of information and knowledge from the company.

The Resource-Based Value (RBV) theory explains that company resources as a source of sustainable excellence must have four things, namely 1) valuable resources, 2) rare resources, 3) inimitable (imperfectly imitable) resources, and 4) non-equivalent strategic substitutes (non-constitutability; Barney, 1991). Human resources capable of having a sustainable competitive advantage are resources that can provide positive performance for a company. Knowledge management is one of the organisation's internal resources that can produce competitive advantage, so that it has a positive impact on company performance.

The effects of a study conducted by Mzoughi, Bahri, and Ghachem (2008) show that competitive advantage can improve business performance. Ismail, Rose, Abdullah, and Uli (2010) found that competitive advantage had a significant effect on organisational performance in manufacturing companies in Malaysia based on firm age. Moreover, Kamukama, Ahiauzu, and Ntavi (2011) state that competitive advantage can improve business performance in microfinance institutions in Uganda. Competitive advantage can bolster customer retention, relationships, and satisfaction, which results in better company performance (Kamboj \& Rahman, 2017).

Therefore, we now known that competitive advantage essentially mediates the impact of knowledge management on the business performance of silver make SMEs in Gianyar Regency. Given that knowledge management has no noteworthy direct impact on business performance, this relationship lies in mediation.

Thus, Kamboj and Rahman (2017) argue that showcasing capabilities are fundamental for the improvement and implementation of promoting procedures, which empower companies to realise client service excellence with respect to client maintenance, relationship building, and fulfilment, which results in a more corporate execution. In turn, Majeed (2011) posits that the knowledge of managers will be able to make a competitive advantage of the company and its execution, as these focal points lead the company to attain high profit.

These results indicate that optimising knowledge will be able to produce products that are competitive. Competitive products can be viewed in terms of efficiency, item uniqueness, item quality, competitive costs, and item adaptability. Full mediation shows the important role of competitive advantage as a mediator. Visionary silver entrepreneurs will certainly orient themselves to produce products that have competitiveness in the market, but they will also strive to produce products quickly and with the ability to adapt according to market expectations. The ability of silver craft SMEs to produce unique products in terms of design and form is inseparable from the role of knowledge possessed by business actors. Companies require routine practice to produce a unique and quality product design. When the product has a competitive advantage, it will certainly improve business performance because it can be accepted by the market.

\section{CONCLUSIONS}

Based on the results of our study, we may conclude that knowledge management in silver craft SMEs in Gianyar Regency has a significant positive effect on its innovation. The knowledge sharing dimension is the most dominant predictor that reflects 
knowledge management variables. Knowledge sharing that occurs among employees or leaders will certainly facilitate employees in completing ordered products, because they find new ideas about processes and products, following desired product orders. The development of new ideas will certainly engender a good process or product innovation for silver craft SMEs in Gianyar Regency.

Knowledge management in the silver craft SMEs in Gianyar Regency proved to have a significant positive effect on the competitive advantage of the silver craft SMEs in Gianyar Regency. Quality is the dominant dimension that strongly reflects competitive advantage compared to other dimensions. Silver handicraft products are high value products, so excellence in quality in terms of quality, product durability, appearance, and compatibility of design and material are important for the customer. To be able to produce a quality product requires good ideas and knowledge.

Competitive advantage positively and significantly affects business performance in silver craft SMEs in Gianyar Regency. That means silver craft SMEs with superior competitiveness certainly can improve their business performance. Silver craft SMEs capable of creating items at reasonable costs, solid item quality, and aware of client needs will certainly deliver to client expectations, so that these conditions will raise profits.

Competitive advantage significantly mediates the effect of knowledge management on the business performance of silver craft SMEs in Gianyar Regency. It turns out that the competitive advantage possessed by silver craft SMEs in Gianyar Regency can fully mediate the relationship between knowledge management and business performance. The ideal execution of information will be able to create items that are competitive in terms of productivity, item uniqueness, item quality, competitive costs, and item adaptability. When the product has a competitive advantage, it will certainly improve business performance because it can be accepted by the market.

The silver craft SMEs are expected to further enhance knowledge management behaviour, namely by increasing knowledge sharing by participating in exhibition events at the local, national, and international levels. Moreover, silver craft SMEs must improve training for employees or new craftsmen in terms of design, quality, and technology in production process so as to reinvigorate silver craftsmen with superior competitiveness. Regarding the competitive advantage of silver craft SMEs, we expect that they always create products with competitiveness, efficiency, uniqueness, quality, and price. Furthermore, business actors must always pay attention to market tastes. Silver craft SMEs find out and register their intellectual property rights for their products, because that is one of the important forms of protection today for creativity-based products with ever-changing innovations.

This research is limited to but one type of creative industry that has a different character from other types of industries, so the study cannot be generalised to other industries. Furthermore, the assessment of business performance in this study was assessed through perception (measured by Likert Scale), not through financial ratios. This is because the characteristics of silver handicraft SMEs are mostly in the scale of small businesses that do not have detailed records of business performance. This study only captures conditions in a one time period, so it is necessary to consider time periods in a longitudinal manner. This study also did not include the knowledge absorption variable, therefore further research could include the knowledge absorption variable in research models related to knowledge management. 
Given the findings of this study - that the role of knowledge management is relatively small in relation to other variables - future research must consider other variables related to SMEs as exogenous variables that influence innovation and competitiveness. Future studies must examine industry classifications based on company size, company age, SME type, process type, technology type, and control variables.

\section{REFERENCES}

Abu-Jarad, I.Y., Yusof, N.A., \& Nikbin, D. (2010). A review paper on organizational culture and organizational performance. International Journal of Business and Social Science, 1(3), 26-46. https://doi.org/10.1108/01443570610710579

Adams, G.L., \& Lamont, B.T. (2003). Knowledge management systems and developing sustainable competitive advantage. Journal of Knowledge Management, 7(2), 142-154 https://doi.org/ 10.1108/13673270310477342

Al-Sa'di, A.F., Abdallah, A.B., \& Dahiyat, S.E. (2017). The mediating role of product and process innovations on the relationship between knowledge management and operational performance in manufacturing companies in Jordan. Business Process Management Journal, 23(2), 349-376. https://doi.org/10.1108/BPMJ-03-2016-0047

Alrubaiee, L., Hanandeh, R.A.E.D., \& Ali, R.A.L. (2015). Investigating the relationship between knowledge management processes and organizational performance the mediating effect of organizational innovation. International Review of Management and Business Research, 4(4), 989-1009.

Apak, S., \& Atay, E. (2014). Global innovation and knowledge management practice in small and medium enterprises (SMEs) in Turkey and the Balkans. Procedia - Social and Behavioral Sciences, 150, 1260-1266. https://doi.org/10.1016/j.sbspro.2014.09.142

Aziz, N.N.A., \& Samad, S. (2016). Innovation and competitive advantage: moderating effects of firm age in foods manufacturing SMEs in Malaysia. Procedia Economics and Finance, 35, 256-266. https://doi.org/10.1016/s2212-5671(16)00032-0

Barney, J. (1991). Firm resources and sustained competitive advantage. Journal of Management, 17(1), 99-120. https://doi.org/10.1177/014920639101700108

Budhi, M.K.S., Lestari, N.P.N.E., Suasih, N.N.R., \& Wijaya, P.Y. (2020). Strategies and policies for developing SMEs based on creative economy. Management Science Letters, 10(10), 2301-2310. https://doi.org/10.5267/j.msl.2020.3.005

Byukusenge, E., Munene, J., \& Orobia, L. (2016). Knowledge management and business performance: Mediating effect of innovation. Journal of Business and Management Sciences, 4(4), 8292. https://doi.org/10.12691/JBMS-4-4-2

Carneiro, A. (2000). How does knowledge management influence innovation and competitiveness?. Journal of Knowledge Management, 4(2), 87-98. https://doi.org/10.1108/13673270010372242

Chiou, T.Y., Chan, H.K., Lettice, F., \& Chung, S.H. (2011). The influence of greening the suppliers and green innovation on environmental performance and competitive advantage in Taiwan. Transportation Research Part E: Logistics and Transportation Review, 47(6), 822-836. https://doi.org/10.1016/j.tre.2011.05.016

Darroch, J. (2005). Knowledge management, innovation and firm performance. Journal of Knowledge Management, 9(3), 101-115. https://doi.org/10.1108/13673270510602809

Darroch, J., \& Mcnaughton, R. (2002). Examining the link between knowledge management practices and types of innovation. Journal of Intellectual Capital, 3(3), 210-222. https://doi.org/10.1108/14691930210435570 
Diab, S.M. (2013). Using the competitive dimensions to achieve competitive advantage (A study on Jordanian private hospitals). International Journal of Academic Research in Business and Social Sciences, 3(7), 138-150. https://doi.org/10.6007/ijarbss/v3-i7/101

Directorate General for National Export Development. (2016). Shining Silver Jewellery. Export News, Ditjen PEN/MJL/51/VII/2016

Directorate General for National Export Development. (2012). Indonesian Gold and Jewellery in the World. Export News, Ditjen PEN/MJL/XXII/08/2012

Fahy, J. (2000). The resource-based view of the firm: Some stumbling-blocks on the road to understanding sustainable competitive advantage. Journal of European Industrial Training, 24(2/3/4), 94-104. https://doi.org/10.1108/03090590010321061

Ferreira, J.J., Garrido Azevedo, S., \& Fernández Ortiz, R. (2011). Contribución del Enfoque de Recursos y Capacidades y la Orientación Emprendedora en el Crecimiento de las Pequeñas Empresas. Cuadernos de Gestión, 11(1), 95-116. https://doi.org/10.5295/cdg.100185jf

Ghozali, I. (2012). Structural equation modelling, alternative method with partial least square. Semarang: Diponegoro University Press.

Goel, R.K., \& Rich, D.P. (1997). On the adoption of new technologies. Applied Economics, 29, 513518. https://doi.org/10.1080/000368497327001

Ha, S.T., Lo, M.C., \& Wang, Y.C. (2016). Relationship between knowledge management and organizational performance: A test on SMEs in Malaysia. Procedia - Social and Behavioral Sciences, 224, 184-189. https://doi.org/10.1016/j.sbspro.2016.05.438

Huang, J.W., \& Li, Y.H. (2009). The mediating effect of knowledge management on social interaction and innovation performance. International Journal of Manpower, 30(3), 285-301. https://doi.org/10.1108/01437720910956772

Ismail, A.I., Rose, R.C., Abdullah, H., \& Uli, J. (2010). The relationship between organisational competitive advantage and performance. Asian Academy of Management Journal, 15(2), 157-173.

Kamboj, S., \& Rahman, Z. (2017). Market orientation, marketing capabilities and sustainable innovation: The mediating role of sustainable consumption and competitive advantage. Management Research Review, 40(6), 698-724. https://doi.org/10.1108/MRR-09-2014-0225

Kamukama, N., Ahiauzu, A., \& Ntayi, J.M. (2011). Competitive advantage: Mediator of intellectual capital and performance. Journal of Intellectual Capital, 12(1), 152-164. https://doi.org/ 10.1108/14691931111097953

Kamya, M.T., Ntayi, J.M., \& Ahiauzu, A. (2010). Knowledge management and competitive advantage: The interaction effect of market orientation. African Journal of Business Management, 4(4), 2971-2980.

Kaplan, R., \& Norton, D. (2007). Using the Balanced Scorecard. Harvard Business Review, 75-85.

Kaveh, D., Bamipur, E.M., Far, M.S., \& Far, M.S. (2015). The relationship between knowledge management and competitive advantage: a case study in small and medium-sized companies in the packaging industry of Khorasan Razavi. European Online Journal of Natural and Social Sciences Special Issue on New Dimensions in Economics, 7(1), 650-659.

Keen, P.G.W. (1991). Every Manager's Guide to Information Technology. Boston: Harvard Business School Press.

Kipesha, E.F. (2013). Performance of microfinance institutions in Tanzania: Integrating financial and non-financial metrics. European Journal of Business and Management, 5(4), 94-105.

Kuhl, M.R., Cunha, J.C., Macaneiro, M.B., \& Cunha, S.K. (2016). Relationship between innovation and sustainable performance. International Journal of Innovation Management, 20(06), 1650047. https://doi.org/10.1142/S136391961650047X 
Kumarawadu, P. (2009). Achieving competitive advantage through knowledge management initiatives in small and medium software industry. Journal of Information \& Knowledge Management, 07(04), 255-265. https://doi.org/10.1142/s0219649208002135

Kuncoro, W., \& Suriani, W.O. (2018). Achieving sustainable competitive advantage through product innovation and market driving. Asia Pacific Management Review, 23(3), 186-192. https://doi.org/10.1016/j.apmrv.2017.07.006

Lakhal, L. (2009). Impact of quality on competitive advantage and organizational performance. Journal of the Operational Research Society, 60(5), 637-645. https://doi.org/10.1057/palgrave.jors. 2602601

Latan, H., \& Ghozali, I. (2012). Partia least square, concept, technique, and application 2.0 M3. Semarang: Diponegoro University Press.

$\mathrm{Ma}, \mathrm{H}$. (2000). Competitive advantage and firm performance. Competitiveness Review, 10(2), 15-32. https://doi.org/10.1108/eb046396

Madan, P., \& Khanka, S. (2011). Contribution of knowledge management practices in creating sustainable competitive advantage for business schools in India. Journal of Information \& Knowledge Management, 09(04), 387-397. https://doi.org/10.1142/s0219649210002760

Majeed, S. (2011). The impact of competitive advantage on organizational performance. European Journal of Business and Management, 3(4), 191-196. https://doi.org/10.1016/j.accinf.2006.12.001

Meutia, \& Ismail, T. (2013). The development of entrepreneurial social competence and business network to improve competitive advantage and business performance of small medium sized enterprises: a case study of batik industry in Indonesia. Procedia - Social and Behavioral Sciences, 65, 46-51. https://doi.org/10.1016/j.sbspro.2012.11.089

Migdadi, M.M., Zaid, M.K.A., Yousif, M., Almestarihi, R., \& Al-Hyari, K. (2017). An empirical examination of knowledge management processes and market orientation, innovation capability, and organisational performance: Insights from Jordan. Journal of Information \& Knowledge Management, 16(1), 1750002, https://doi.org/10.1142/s0219649217500022

Mzoughi, N., Bahri, N., \& Ghachem, M.S. (2008). Impact of supply chain management and ERP on organizational performance and competitive advantage: Case of tunisian companies. Journal of Global Information Technology Management, 11(3), 24-46. https://doi.org/10.1080/1097198X.2008.10856472

Obeidat, B.Y., Al-Suradi, M.M., Masa'deh, R., \& Tarhini, A. (2016). The impact of knowledge management on innovation: An empirical study on Jordanian consultancy firms. Management Research Review, 39(10), 1214-1238. https://doi.org/10.1108/MRR-09-2015-0214

Oztekin, A., Delen, D., Zaim, H., Turkyilmaz, A., \& Zaim, S. (2015). The Influence of Knowledge Management on Financial and Non-Financial Performance. Journal of Information \& Knowledge Management, 14(2), 1550013. https://doi.org/10.1142/s0219649215500136

Peteraf, M.A. (1993). The cornerstones of competitive advantage: A resource-based view. Strategic Management Journal, 14(3), 179-191. https://doi.org/10.1002/smj.4250140303

Porter, M.E. (1990). The Competitive Advantage of Nations. (cover story). Harvard Business Review, March-April 1990 Issue.

Purnomo, R. (2011). Resource-Based View dan keunggulan bersaing berkelanjutan: Sebuah telaah kritis terhadap pemikiran Jay Barney (Resource-Based View and sustainable competitive advantage: A critical review of Jay Barney's thought). Proceeding Seminar Nasional \& Call for Papers (SCA-1), 01(01), 1-16 
Rahman, N.A.A., \& Ramli, A. (2014). Entrepreneurship Management, Competitive Advantage and Firm Performances in the Craft Industry: Concepts and Framework. Procedia - Social and Behavioral Sciences, 145, 129-137. https://doi.org/10.1016/j.sbspro.2014.06.019

Rahyuda, I.K. (2016). Metode Penelitian Bisnis (Business Research Methods). Denpasar: Udayana University Press.

Sachitra, V. (2017). Review of competitive advantage measurements: reference on agribusiness sector. Journal of Scientific Research and Reports, 12(6), 1-11. https://doi.org/10.9734/jsrr/2016/30850

Sarkindaji, B.D. (2014). Knowledge management and organizational performance of mobile service firms in Nigeria: A proposed framework. Information and Knowledge Management, 4(11), 84-95. Retrieved from https://iiste.org/Journals/index.php/SME'S/article/view/17216 on August 31, 2020.

Sarkindaji, B.D., Bin Hashim, N.A., \& Abdullateef, A.O. (2014). Knowledge management and organizational performance of mobile service firms in Nigeria: A proposed framework. Information and Knowledge Management, 4(11), 84-95.

Sugiyono. (2013). Metode Penelitian Manajemen (Management Research Methods). Bandung: Alfabeta.

Tan, Y.C., Mavondo, F., \& Worthington, S. (2011). Organisational Capabilities and Relationship Quality Performance Implications for Palm Oil Processors in Malaysia. Asia Pacific Journal of Marketing and Logistics, 23(2), 152-164.

Tanriverdi. (2017). Information technology relatedness, knowledge management capability, and performance of multibusiness firms. MIS Quarterly, 29(2), 311. https://doi.org/10.2307/25148681

Tseng, S.M., \& Lee, P.S. (2014). The effect of knowledge management capability and dynamic capability on organizational performance. Journal of Enterprise Information Management, 27(2), 158-179. https://doi.org/10.1108/JEIM-05-2012-0025

Valmohammadi, C., \& Ahmadi, M. (2015). The impact of knowledge management practices on organizational performance: A balanced scorecard approach. Journal of Enterprise Information Management, 28(1), 131-159. https://doi.org/10.1108/JEIM-09-2013-0066

Wang, C.L., Hult, G.T.M., Ketchen, D.J., \& Ahmed, P.K. (2009). Knowledge management orientation, market orientation, and firm performance: An integration and empirical examination. Journal of Strategic Marketing, 17(2), 99-12. https://doi.org/10.1080/09652540902879326

Wang, S., \& Noe, R.A. (2010). Knowledge sharing: A review and directions for future research. Human Resource Management Review, 20(2), 115-131 https://doi.org/10.1016/j.hrmr.2009.10.001

Wang, Z., \& Wang, N. (2012). Knowledge sharing, innovation and firm performance. Expert Systems with Applications, 39(10), 8899-8908. https://doi.org/10.1016/j.eswa.2012.02.017

Ward, P.T., McCreery, J.K., Ritzman, L.P., \& Sharma, D. (2007). Competitive priorities in operations management. Decision Sciences, 29(4), 1035-1046. https://doi.org/10.1111/j.15405915.1998.tb00886.x

Wernerfelt, B. (1984). A resource-based view of the firm. Strategic Management Journal, 5(2), 171180. https://doi.org/10.1002/smj.4250050207

Wijaya, P.Y., Rahyuda, I.K., Yasa, N.N.K., \& Sukaatmadja, I.P.G. (2019). Dilemma of innovation in silver craft SMEs in Gianyar Regency of Bali Province, Indonesia. Revista Espacios, 40(22), 15-22. ISSN 07981015

Yousif Al-Hakim, L.A., \& Hassan, S. (2013). Knowledge management strategies, innovation, and organisational performance. Journal of Advances in Management Research, 10(1), 58-71. https://doi.org/10.1108/09727981311327767

Yusof, M.N., \& Bakar, A.H.A. (2012). Knowledge management and growth performance in construction companies: A framework. Procedia - Social and Behavioral Sciences, 62, 128-134. https://doi.org/10.1016/j.sbspro.2012.09.022 


\section{Authors}

The contribution share of authors is equal and amounted to $50 \%$ each of them.

\section{Putu Yudy Wijaya}

PhD in Marketing Management (2019, Udayana University, Indonesia); Master's in financial management (2007, Airlangga University, Indonesia); Bachelor of Economic Development (2004, Udayana University, Indonesia). His research interests include marketing, financial management, business management, and strategic management.

Correspondence to: Dr. Putu Yudy Wijaya, SE., M.Si., Hindu Indonesia University, Faculty of Economics Business and Tourism, Jalan Sangalangit, Tembau-Denpasar, Indonesia, e-mail: yudywijaya333@unhi.ac.id

ORCID (1) http://orcid.org/0000-0002-7686-8952

\section{Ni Nyoman Reni Suasih}

PhD in Economic Science (2016, Udayana University, Indonesia); Master's in Economic Development (2012, Udayana University, Indonesia); Bachelor of Local Government Budgeting (2009, Institute of Home Affair Government, Indonesia). Her research interests include economic development, agriculture, rural development, and government budgeting.

Correspondence to: Dr. Ni Nyoman Reni Suasih, S.IP., M.Si., Udayana University, Faculty of Economics and Business, Jalan P.B. Sudirman, Denpasar, Bali, 80112, Indonesia, e-mail: renisuasih@unud.ac.id

ORCID ㄴ) http://orcid.org/0000-0002-1992-4540

\section{Acknowledgements and Financial Disclosure}

We thank the Bali Provincial Government, Gianyar Regency Government, Indonesian Chamber of Commerce and Industry (Branch in Gianyar) for the support of data and information. We also thank the silver crafts businessmen who have been willing to become research respondents.

\section{Copyright and License}

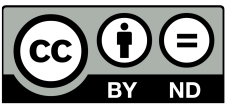

This article is published under the terms of the Creative Commons

Attribution - NoDerivs (CC BY-ND 4.0) License http://creativecommons.org/licenses/by-nd/4.0/

Published by Cracow University of Economics - Krakow, Poland 